\title{
Heavy metal levels in Tilapia zilli samples from North Central Nigerian rivers
}

\author{
Ogah E. ${ }^{1 *}$, Malu S. P. ${ }^{1}$, Ushie O. A. ${ }^{1}$, Longbap B. D. ${ }^{1}$ and Abiaziem C. V. ${ }^{2}$ \\ ${ }^{1}$ Department of Chemical Science, Federal University, Wukari, Taraba State, Nigeria. \\ 2Department of Science Laboratory Technology, Federal Polytechnic Ilaro, Ogun State, Nigeria. \\ *Corresponding Author: Email: uhinyohe@gmail.com. Tel: 2347061110996.
}

Copyright $@ 2016$ Ogah et al. This article remains permanently open access under the terms of the Creative Commons Attribution License 4.0, which permits unrestricted use, distribution, and reproduction in any medium, provided the original work is properly cited.

Received 30th August, 2016; Accepted 16th October, 2016

\begin{abstract}
The determination of $\mathrm{Cd}, \mathrm{Cr}, \mathrm{Mn}, \mathrm{Ni}, \mathrm{Pb}$ contents in Tilapia zilli of North Central Nigeria Rivers were made using Atomic Absorption spectrophotometric technique. The method of acid digestion in 1:5:1, 70\% perchloric, concentrated nitric and concentrated sulphuric acid was used to liberate the metals. The concentration of heavy metals $(\mathrm{mg} / \mathrm{kg})$ during the wet season ranged between $0.0-25.4,0.1-40.2,1.4-435.1,0.5-15.7,0.4-25.4$ for $\mathrm{Cd}, \mathrm{Cr}, \mathrm{Mn}, \mathrm{Ni}$ and $\mathrm{Pb}$ respectively, while in the dry season the concentrations ranged between $0.3-13.0,0.8-31.2,5.2-344.2,0.6$ $25.1,0.1-45.6$ for $\mathrm{Cd}, \mathrm{Cr}, \mathrm{Mn}, \mathrm{Ni}$ and $\mathrm{Pb}$ respectively. The mean concentration of the heavy metals follow the pattern $\mathrm{Mn}>\mathrm{Cr}>\mathrm{Pb}>\mathrm{Ni}>\mathrm{Cd}$ during both seasons showing that once heavy metals are bioaccumulated they are lost slowly or not all. The results also show that the concentrations recorded for $\mathrm{Cd}, \mathrm{Cr}, \mathrm{Mn}, \mathrm{Ni}$ and $\mathrm{Pb}$ are above the guideline values of WHO and FEPA and are not fit for human consumption.
\end{abstract}

Key words: Bioaccumulation aquatic organisms, heavy metals, pollution, river.

\section{INTRODUCTION}

Heavy metals are reasonably dangerous to the aquatic environment. This can be due to their toxicity, wide sources, lack of biodegradable properties, and accumulative tendencies (Mansouri et al., 2012; Rezaee et al., 2011; Salati and Moore, 2010). Usually, concentrations of heavy metals in aquatic ecosystems are monitored by measuring its concentration in water, sediments, and biota, which generally exist in lower levels in water and attain elevated concentration in sediments and biota (Ebrahimpour and Mushrifah, 2008).

Aquatic ecosystem is the ultimate sink of almost everything heavy metals inclusive. Pollution of heavy metals in aquatic environment is a growing global problem and currently it has assumed an alarming proportion. There are numerous sources of heavy metals; such as anthropogenic activities like draining of sewage, dumping of hospital wastes and recreational activities. Conversely, metals also occur in small amounts naturally and can enter into aquatic system through leaching of rocks, airborne dust, forest fires and vegetation
(Fernandez and Olalla, 2000). Heavy metals are continuously being deposited and incorporated in water, sediment and aquatic organisms as a result of their inability to be degraded (Linnik and Zubenko, 2000), thus causing heavy metal pollution in water bodies.

The indiscriminate disposal of industrial effluents and other wastes in rivers and lakes contribute greatly to the poor quality of river water (Chindah et al., 2004; Emongore et al., 2005; Furtado et al., 1998. Among environmental pollutants, metals are of particular interest in view of their potential toxic effect and ability to bioaccumulate in aquatic ecosystems (Censi et al., 2006). Heavy metals including both essential and nonessential elements have a particular significance in ecotoxicology, as they are toxic to living organisms (Storelli et al., 2005). Bioaccumulation and magnification is capable of leading to toxic level of these metals in fish even at minimal level of exposure. This work set out as its aim to investigate the concentration of heavy metals in Tilapia zilli in the rivers of North Central Nigeria. 


\section{MATERIALS AND METHODs}

\section{Sample Collection}

Samples (fish) were collected at the peak of both the dry (February to March) and wet season (August to September). Dugout canoes with paddles were used for sampling from the stations. Fish samples were collected using gill nets, baited hook and lines and traps. Between five and seven of each fish species weighing between 1.5 to $2.5 \mathrm{~kg}$ were collected. The fish samples were placed in plastic bags and stored in ice box and taken to the laboratory after cleaning with distilled water to remove any adhering dirt.

\section{Sample Treatment}

The fish samples after defrosting were dissected using stainless steel dissection instruments, with surgical gloves on and gills, liver and muscle tissue were selected. After dissection, all tissue samples were separately oven-dried at $105^{\circ} \mathrm{C}$ to constant weight and were each ground to powder. At least three laboratory samples of fish muscle, liver and gill were prepared from each fish specimen. $1 \mathrm{gram}$ of each powdered sample was digested using a mixture of $1: 5: 1,70 \%$ perchloric, concentrated nitric and concentrated sulphuric acid at 80 $\pm 5^{\circ} \mathrm{C}$ in a fume chamber, until a colourless liquid was obtained. Then $5 \mathrm{~mL}$ of bidistilled water $\left(\mathrm{H}_{2} \mathrm{O}\right)$ and $1 \mathrm{~mL}$ of $35 \% \mathrm{H}_{2} \mathrm{O}_{2}$ solution (35\% pure for analysis, Merck) (Staniskiene et al., 2006).

\section{Stock Solutions}

\section{Cadmium}

$1.000 \mathrm{~g}$ of cadmium metal was dissolved in $20 \mathrm{ml}$ of $1+1$ $\mathrm{HCl}$ and then diluted to $1000 \mathrm{~mL}$ to make $1000 \mathrm{mgL}^{-1} \mathrm{Cd}$ stock solution. An intermediate stock solution of $100 \mathrm{mgL}^{-}$

${ }^{1} \mathrm{Cd}$ was made from the stock solution and a series of working standards of the following concentrations were prepared: $0.0,0.5,1.0,2.0,3.0,5.0 \mathrm{mgL}^{-1} \mathrm{Cd}$. The absorbance was determined on AAS AAnalyst 400 and wavelength set at $228.9 \mathrm{~nm}$ (APHA, 1990).

\section{Chromium}

$2.828 \mathrm{~g}$ of anhydrous potassium dichromate $\left(\mathrm{K}_{2} \mathrm{Cr}_{2} \mathrm{O}_{7}\right)$ was dissolved in $200 \mathrm{~mL}$ distilled water and $1.5 \mathrm{~mL}$ concentrated $\mathrm{HNO}_{3}$ was added and then diluted to 1000 $\mathrm{mL}$ with distilled water to make $1000 \mathrm{mgL}^{-1} \mathrm{Cr}$. An intermediate stock solution of $100 \mathrm{mgL}^{-1} \mathrm{Cr}$ was made from the stock solution and a series of working standards of the following concentrations were prepared: $0.0,0.5$, 1.0, 2.0, 3.0, $5.0 \mathrm{mg} \mathrm{L}^{-1} \mathrm{Cr}$. The absorbance was determined on AAS AAnalyst 400 and wavelength set at $357.9 \mathrm{~nm}$.

\section{Manganese}

$1.000 \mathrm{~g}$ of manganese metal is dissolved in $50 \mathrm{~mL}$ of concentrated $\mathrm{HCl}$. The solution was then made up to $1 \mathrm{~L}$ in a volumetric flask with distilled deionized water. An intermediate stock solution of $100 \mathrm{mgL}^{-1} \mathrm{Mn}$ was made from the stock solution and a series of working standards of the following concentrations were prepared: $0.0,0.5$, 1.0, 2.0, 3.0, $5.0 \mathrm{mg} \mathrm{L}^{-1}$ (APHA, 1990).

\section{Nickel}

$1.000 \mathrm{~g}$ of nickel is dissolved in $20 \mathrm{~mL}$ of concentrated $\mathrm{HNO}_{3}$. The solution was diluted to $1 \mathrm{~L}$ in a volumetric flask with distilled deionized water. An intermediate stock solution of $100 \mathrm{mgL}^{-1} \mathrm{Ni}$ was made from the stock solution and a series of working standards of the following concentrations were prepared: $0.0,0.5,1.0,2.0$, 3.0, $5.0 \mathrm{mg} \mathrm{L}^{-1}$ The absorbance was determined on AAS and wavelength set at $232 \mathrm{~nm}(\mathrm{APHA}, 1990)$..

\section{Lead}

$1.598 \mathrm{~g}$ of lead nitrate $\mathrm{Pb}\left(\mathrm{NO}_{3}\right)_{2}$ was dissolved in $200 \mathrm{~mL}$ distilled water and $1.5 \mathrm{~mL}$ concentrated $\mathrm{HNO}_{3}$ was added and then diluted to $1000 \mathrm{~mL}^{\circ}$ make $1000 \mathrm{mgL}^{-1} \mathrm{~Pb}$. An intermediate stock solution of $100 \mathrm{mgL}^{-1} \mathrm{~Pb}$ was made from the stock solution and a series of working standards of the following concentrations were prepared: $0.0,0.5$, $1.0,2.0,3.0,5.0, \mathrm{mgL}^{-1} \mathrm{~Pb}$. The absorbance was determined on AAS and wavelength set at $283.7 \mathrm{~nm}$ (APHA, 1990).

\section{Instrumentation}

The measurements were performed using the Perkin Elmer ${ }^{\circledR}$ Analyst 400 atomic absorption spectrophotometer (PerkinElmer, Inc. Shelton, CT, USA) equipped with WinLab32 ${ }^{\mathrm{TM}}$ for $A A$ version software, which featured all the tools needed to analyze samples, report and archive data and ensure regulatory compliance. PerkinElmer high efficiency double beam optical system and solid-state deuterium background correction eliminates most interference. A Perkin Elmer corrosion - resistant nebulizer, which can be used for solutions containing HF, was used for all the flame absorption measurements. A single slot air-acetylene $10 \mathrm{~cm}$ burner head was used for all air-acetylene experiments.

\section{Statistical analyses}

Data collected were presented as mean and standard deviation and were subjected to one way analysis of variance (ANOVA) $(p<0.05)$ to assess whether heavy 
Table 1. Elemental concentrations in organs of Tilapia zilli(mgkg $\left.{ }^{-1}\right)$ during the wet season.

\begin{tabular}{|c|c|c|c|c|c|c|c|c|c|c|c|c|c|c|c|}
\hline \multirow{2}{*}{$\begin{array}{l}\text { Sample } \\
\text { locations }\end{array}$} & \multicolumn{5}{|c|}{ Gill } & \multicolumn{5}{|c|}{ Liver } & \multicolumn{5}{|c|}{ Muscle } \\
\hline & $\mathrm{Cd}$ & $\mathrm{Cr}$ & $\mathrm{Mn}$ & $\mathrm{Ni}$ & $\mathrm{Pb}$ & $\mathrm{Cd}$ & $\mathrm{Cr}$ & Mn & $\mathrm{Ni}$ & $\mathrm{Pb}$ & $\mathrm{Cd}$ & $\mathrm{Cr}$ & $\mathrm{Mn}$ & $\mathrm{Ni}$ & $\mathrm{Pb}$ \\
\hline A & 3.1 & 0.9 & 1.4 & 3.0 & 12.0 & 0.8 & 5.4 & 13.3 & 2.9 & 11.1 & 0.3 & 7.0 & 23.6 & 5.0 & 13.2 \\
\hline B & 0.3 & 8.7 & 79.5 & 9.4 & 7.0 & 5.8 & 22.3 & 31.1 & 2.8 & 13.4 & 0.1 & 4.5 & 22.3 & 0.9 & 12.6 \\
\hline C & 0.7 & 13.1 & 17.6 & 1.3 & 0.7 & 2.8 & 25.5 & 26.3 & 11.6 & 1.2 & 3.8 & 18.3 & 5.3 & 3.6 & 4.4 \\
\hline D & 0.0 & 31.8 & 94.4 & 6.6 & 4.1 & 15.1 & 9.3 & 11.9 & 2.2 & 14.2 & 8.7 & 4.9 & 27.7 & 0.5 & 0.4 \\
\hline$E$ & 10.8 & 40.2 & 70.4 & 12.6 & 0.7 & 18.2 & 4.6 & 31.4 & 1.7 & 13.2 & 1.6 & 4.8 & 3.0 & 12.2 & 4.2 \\
\hline $\mathrm{F}$ & 13.0 & 20.2 & 8.2 & 2.1 & 12.1 & 1.6 & 26.7 & 27.6 & 14.0 & 6.9 & 11.6 & 2.4 & 30.8 & 0.9 & 4.4 \\
\hline G & 2.6 & 9.7 & 171.5 & 10.6 & 14.4 & 0.2 & 7.8 & 435.1 & 4.5 & 12.0 & 0.5 & 5.2 & 40.3 & 10.8 & 1.1 \\
\hline $\mathrm{H}$ & 2.1 & 7.7 & 165.3 & 1.6 & 6.4 & 0.7 & 16.6 & 220.4 & 0.8 & 3.4 & 0.8 & 26.4 & 12.8 & 0.9 & 12.6 \\
\hline I & 1.5 & 17.1 & 12.8 & 1.3 & 15.2 & 0.5 & 6.9 & 24.6 & 0.7 & 25.4 & 0.6 & 6.9 & 28.4 & 1.2 & 7.8 \\
\hline J & 1.4 & 12.5 & 23.6 & 6.5 & 2.1 & 1.6 & 15.2 & 14.4 & 0.7 & 0.9 & 7.8 & 4.2 & 38.2 & 3.7 & 0.5 \\
\hline K & 4.7 & 21.6 & 80.0 & 5.7 & 9.8 & 3.4 & 24.0 & 35.6 & 15.7 & 11.2 & 0.9 & 16.0 & 9.2 & 0.8 & 0.9 \\
\hline $\mathrm{L}$ & 0.6 & 24.8 & 40.0 & 8.4 & 13.1 & 2.5 & 16.9 & 40.4 & 9.7 & 2.7 & 0.3 & 6.0 & 36.0 & 1.5 & 0.5 \\
\hline
\end{tabular}

A, Wadata, B, Wurukum, C, Confluence Hotel, D, Lokoja Town, E, Jebba, F, Jebba Bridge, G, Yelwa, H, Gudi, I, Shiroro, J, Kainji, K, Kalong, L, Shendam Town.

Table 2. Elemental concentrations in organs of Tilapia zilli() during the dry season.

\begin{tabular}{|c|c|c|c|c|c|c|c|c|c|c|c|c|c|c|c|}
\hline \multirow{2}{*}{ Sample locations } & \multicolumn{5}{|c|}{ Gill } & \multicolumn{5}{|c|}{ Liver } & \multicolumn{5}{|c|}{ Muscle } \\
\hline & $\mathrm{Cd}$ & $\mathrm{Cr}$ & $\mathrm{Mn}$ & $\mathrm{Ni}$ & $\mathrm{Pb}$ & $\mathrm{Cd}$ & $\mathrm{Cr}$ & $\mathrm{Mn}$ & $\mathrm{Ni}$ & $\mathrm{Pb}$ & $\mathrm{Cd}$ & $\mathrm{Cr}$ & $\mathrm{Mn}$ & $\mathrm{Ni}$ & $\mathrm{Pb}$ \\
\hline M & 2.5 & 10.5 & 112.1 & 7.3 & 0.1 & 13.0 & 26.6 & 142.4 & 16.7 & 15.1 & 2.0 & 1.2 & 11.0 & 1.2 & 16.8 \\
\hline N & 5.3 & 27.9 & 178.1 & 1.1 & 13.4 & 2.2 & 0.9 & 66.8 & 17.4 & 13.5 & 1.4 & 22.1 & 11.0 & 1.4 & 7.0 \\
\hline 0 & 2.8 & 28.4 & 5.2 & 1.8 & 1.0 & 3.8 & 23.0 & 68.2 & 21.4 & 7.0 & 1.4 & 11.9 & 16.2 & 1.2 & 14.2 \\
\hline$P$ & 1.5 & 20.5 & 6.4 & 12.3 & 4.5 & 0.8 & 25.1 & 18.4 & 7.8 & 41.4 & 6.0 & 17.3 & 12.0 & 3.7 & 6.7 \\
\hline$Q$ & 4.0 & 19.5 & 21.2 & 7.6 & 5.3 & 1.6 & 19.3 & 18.4 & 1.3 & 10.4 & 1.5 & 5.0 & 8.0 & 12.2 & 1.1 \\
\hline $\mathrm{R}$ & 6.7 & 8.1 & 13.7 & 1.0 & 14.2 & 2.2 & 1.0 & 21.5 & 1.22 & 23.0 & 3.1 & 31.2 & 394.7 & 8.5 & 8.2 \\
\hline S & 10.6 & 1.2 & 179.6 & 1.6 & 1.0 & 10.6 & 0.0 & 77.9 & 1.7 & 14.5 & 1.2 & 17.4 & 16.3 & 15.5 & 1.7 \\
\hline $\mathrm{T}$ & 2.7 & 29.0 & 105.1 & 6.6 & 7.2 & 2.7 & 17.8 & 38.3 & 6.9 & 3.4 & 1.2 & 9.4 & 33.2 & 2.8 & 0.3 \\
\hline U & 2.1 & 23.0 & 105.1 & 0.6 & 8.2 & 11.0 & 19.7 & 344.2 & 4.1 & 11.4 & 2.0 & 23.0 & 15.9 & 1.0 & 12.6 \\
\hline V & 0.5 & 15.1 & 37.8 & 6.6 & 0.7 & 1.5 & 19.5 & 152.5 & 1.1 & 14.2 & 0.3 & 21.2 & 94.1 & 1.2 & 9.6 \\
\hline W & 11.0 & 7.3 & 104.9 & 1.9 & 10.6 & 2.4 & 15.8 & 39.2 & 7.2 & 3.9 & 2.3 & 8.9 & 10.0 & 0.8 & 7.4 \\
\hline$x$ & 0.6 & 26.0 & 134.0 & 1.5 & 7.0 & 1.6 & 29.1 & 33.6 & 12.0 & 1.0 & 2.6 & 20.8 & 59.7 & 25.1 & 45.6 \\
\hline
\end{tabular}

M, Wadata, N, Wurukum, O, Confluence Hotel, P, Lokoja Town, Q, Jebba, R, Jebba Bridge, S, Yelwa, T, Gudi, U, Shiroro, V, Kainji, W, Kalong, X, Shendam Town.

metals varied significantly between animals. All statistical calculations were performed with SPSS 9.0 for Windows (Ozdamar, 1991).The analysis revealed that the comparison of concentrations in the organs show no significant variation between the wet and dry seasons. Comparison of concentration of the elements showed no significant difference between elements except the concentrations of manganese.

\section{RESULTS AND DISCUSION}

The concentrations of the various elements in Tilapia zilli during the wet season for the gills, liver and muscle are presented in Table 1 while Table 2 presents the concentrations during the dry season for the gills, liver and muscle. Figures 1 to 6 represent the concentrations of the various elements as per the seasons. The maximum concentration of cadmium during the wet season $\left(25.4 \mathrm{mgkg}^{-1}\right)$ was detected in the muscle while the minimum $0.0 \mathrm{mgkg}^{-1}$ was also in the muscle (Table 1), while the lowest and maximum detected concentrations of $\mathrm{Cd}$ during the dry were $0.3 \mathrm{mgkg}^{-1}$ (muscle) and 13.0 $\mathrm{mgkg}^{-1}$ (gill) respectively Table 2 . These values apart from where concentrations were less than, LOD are above Federal Environmental protection agency (FEPA, 2003) and (WHO, 1985) permissible limits of $\mathrm{Cd}$ in fish which is $0.05 \mathrm{ppm}$.

Cadmium is a highly toxic non-essential heavy metal and it plays no role in biologica I process in living 


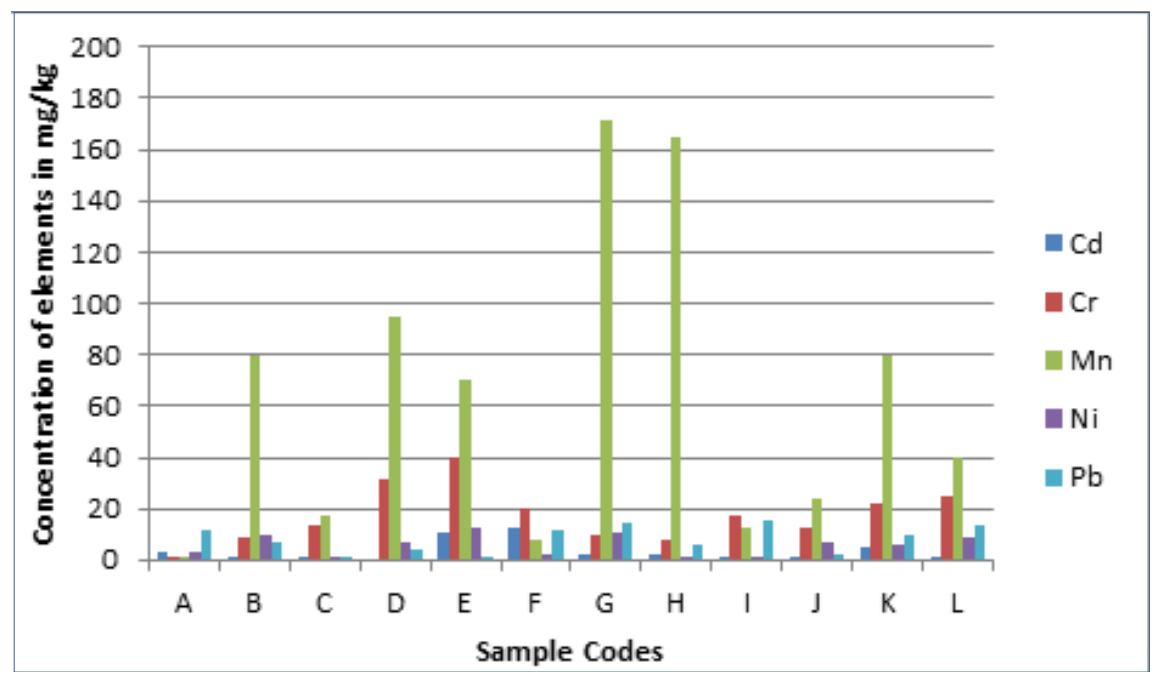

Figure 1. Concentration of heavy metals in gills during the wet season.

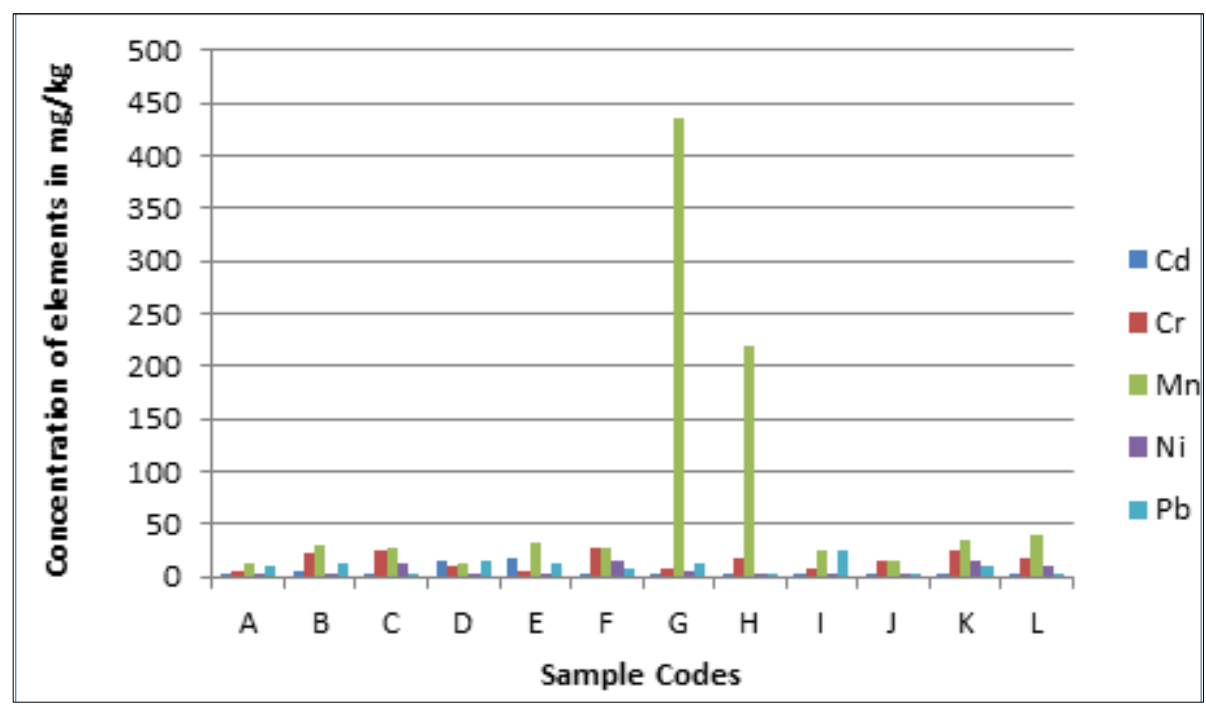

Figure 2. Concentration of heavy metals in liver during wet season.

organisms. The levels of $\mathrm{Cd}$ present in the selected organs of $T$. zilli may be due to agricultural activities in the investigated area (Ambedkar and Muniyan, 2011).

The maximum concentration of chromium during the wet season was $40.2 \mathrm{mgkg}^{-1}$ while the minimum concentration was $0.1 \mathrm{mgkg}^{-1}$ (muscle). However, the peak and least concentrations of chromium during the dry season were $31.2 \mathrm{mgkg}^{-1}$ and $0.8 \mathrm{mgkg}^{-1}$ respectively.

Chromium levels were above the WHO (1985) and FEPA (2003) standards limits of $0.15 \mathrm{mgkg}^{-1}$ for fish food. $\mathrm{Cr}$ plays an important role in glucose metabolism. Chromium bioaccumulation in fish has been implicated in impaired respiratory and osmoregulatory functions through structural damage to gill epithelium (Heath, 1991). The concentration of chromium levels in the different organs of the freshwater fish and their presence could be linked to waste water discharge from the agricultural related activities that are prevalent in the investigated areas.

The concentrations of $\mathrm{Mn}$ were highest in all the organs investigated. The maximum concentration of $\mathrm{Mn}$ during the wet season $\left(435.1 \mathrm{mgkg}^{-1}\right)$ was detected in the gill while the minimum $1.4 \mathrm{mgkg}^{-1}$ was also in the gill (Table 1), while the lowest and maximum detected concentrations of $\mathrm{Mn}$ during the dry were $344.2 \mathrm{mgkg}^{-1}$ (liver) and $5.2 \mathrm{mgkg}^{-1}$ (gill) respectively (Table 2). These concentration values are above FEPA (2003) and WHO (1985) permissible limits of $\mathrm{Mn}$ in fish which are both $0.05 \mathrm{ppm}$.

The health effects of manganese exposure in humans are not well understood. Although dietary manganese is 


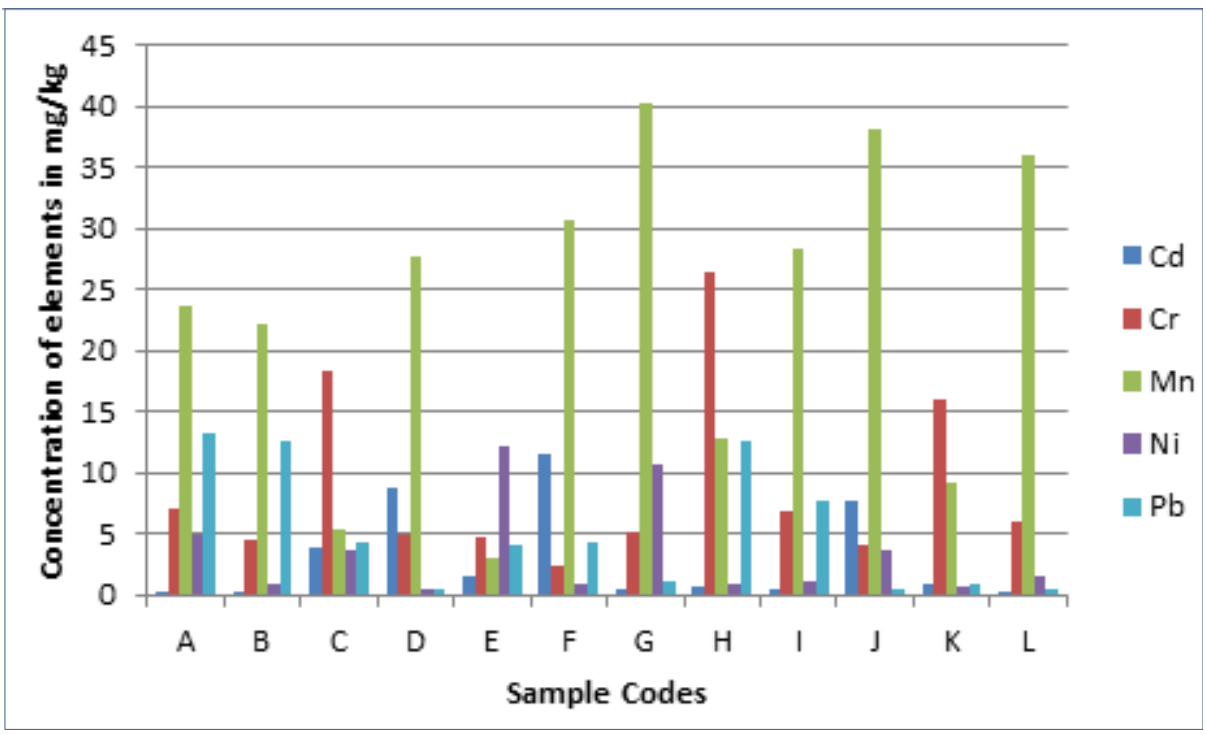

Figure 3. Concentration of heavy metals in muscle during wet season.

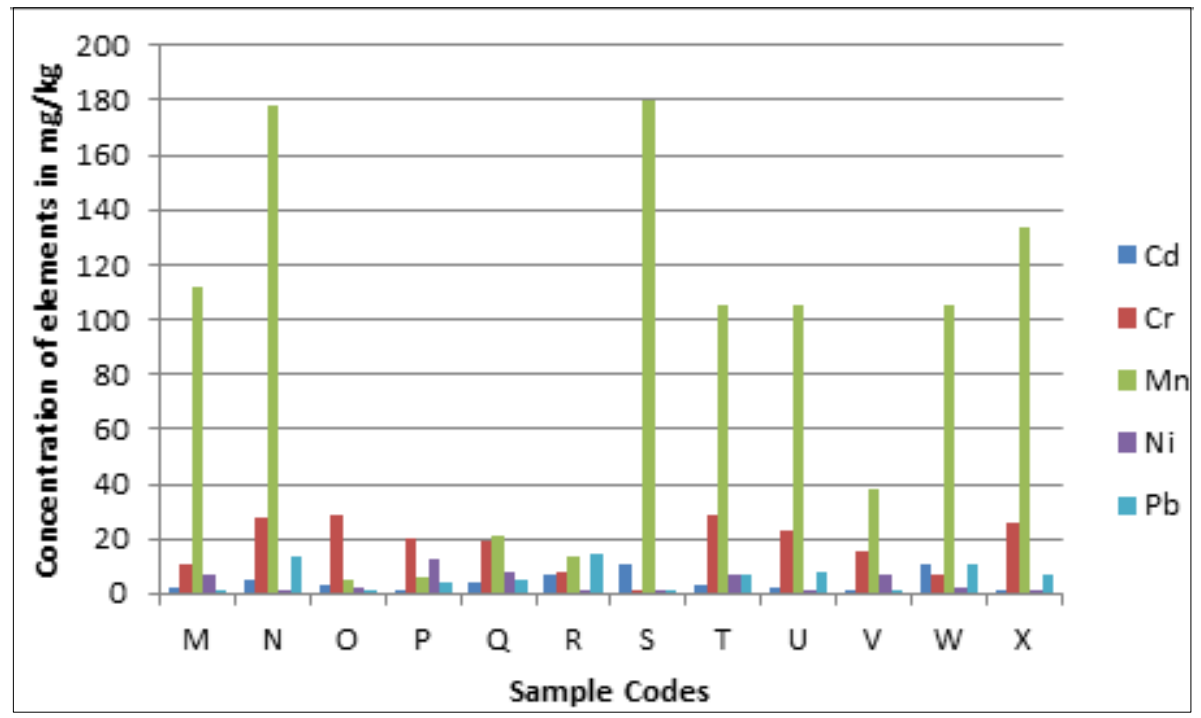

Figure 4. Concentration of heavy metals in gills during the dry season.

an essential nutrient, high intake of manganese has been shown to be toxic. Manganese is best characterized asneurotoxin, occupational exposures are associated with characteristic syndrome called manganism which involves both psychiatric symptoms and Parkinsonism features (Dobson et al., 2004).

The highest reported concentration of nickel during the wet season was $15.7 \mathrm{mgkg}^{-1}$ (liver) while the least concentration was $0.5 \mathrm{mgkg}^{-1}$ (liver). The maximum and minimum concentrations of nickel during the dry season were $25.1 \mathrm{mgkg}^{-1}$ and $0.6 \mathrm{mgkg}^{-1}$ respectively.

The estimated maximum guideline (USFDA, 1993) for $\mathrm{Ni}$ is 70 to $80 \mathrm{mgkg}^{-1}$. Thus the concentrations of $\mathrm{Ni}$ in all the samples were far below the stipulated limit. The major source of $\mathrm{Ni}$ for humans is food and uptake from natural sources, as well as food processing. Increased incidence of cancer of the lung and nasal cavity caused by high intake of $\mathrm{Ni}$ has been reported in workers in Ni smelters.

The maximum concentration of $\mathrm{Pb}$ during the wet season (25.4 $\left.\mathrm{mgkg}^{-1}\right)$ was detected in the liver while the minimum $0.4 \mathrm{mgkg}^{-1}$ was in the muscle, while the lowest and highest detected concentrations of $\mathrm{Pb}$ during the dry season were $0.1 \mathrm{mgkg}^{-1}$ (gill) and $45.6 \mathrm{mgkg}^{-1}$ (muscle) respectively.

Lead is a well-known toxicant that has several deleterious effects even at very low concentrations (Eneji 


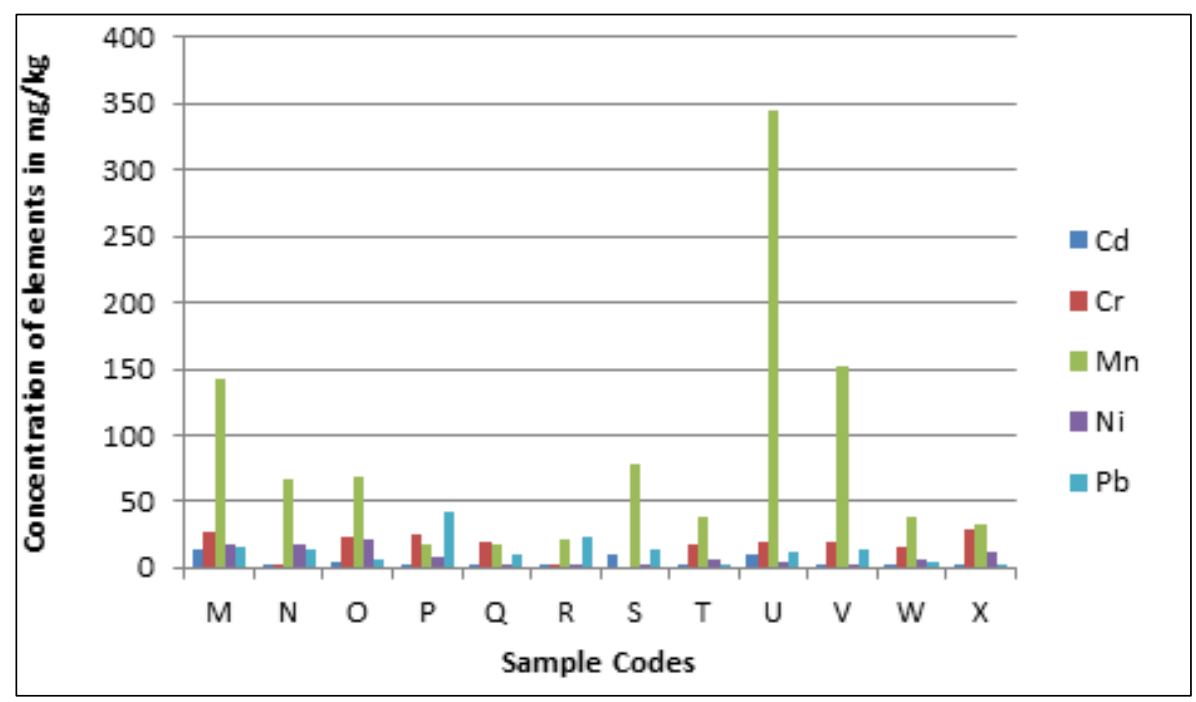

Figure 5. Concentration of heavy metals in liver during the dry season.

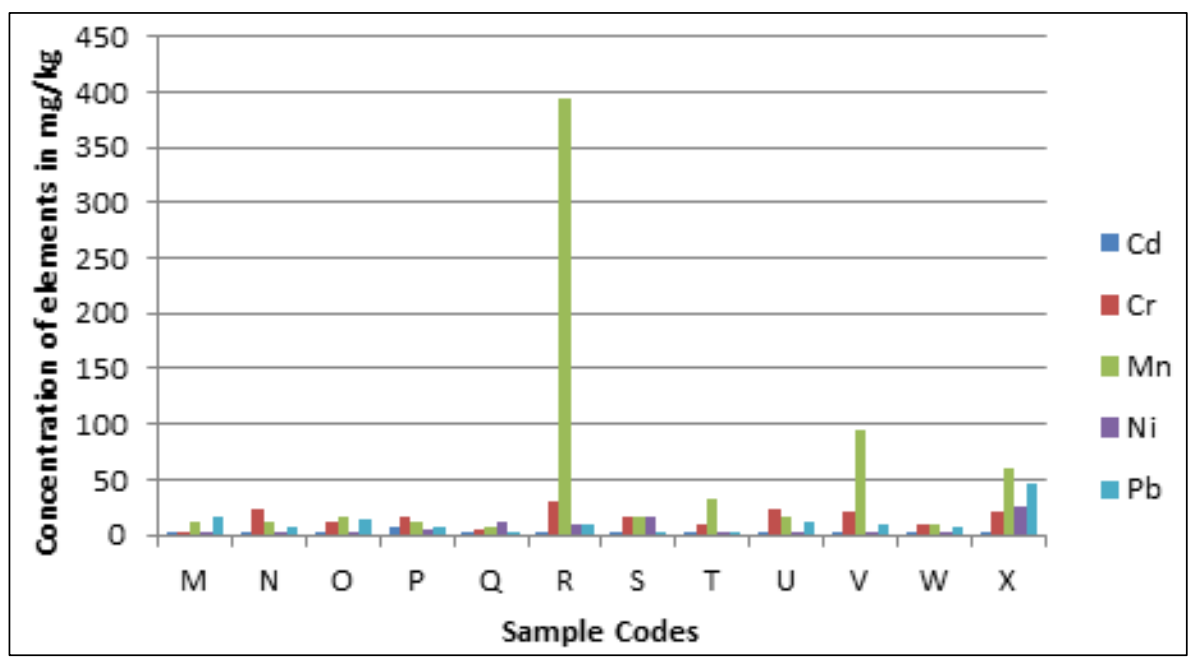

Figure 6. Concentration of heavy metals in muscle during the dry season.

et al., 2011). The maximum tolerable limit of $\mathrm{Pb}$ in fish and meat in the European Union it is $0.2 \mathrm{mg} / \mathrm{kg}$ (European Commission, 2000). The concentrations reported in this work are reasonably higher than those prescribed by the European Commission. It is highly toxic to aquatic organisms, especially fish and the biological effects of sublethal concentrations of lead include delayed embryonic development, suppressed reproduction, growth inhibition, elevated mucous formation, neurological problems and kidney dysfunction (Rompala et al., 1984, Leland and Kuwabara. 1985).

The pattern of metal concentration in Tilapia zilli was $\mathrm{Mn}>\mathrm{Cr}>\mathrm{Pb}>\mathrm{Ni}>\mathrm{Cd}$ during both the wet and dry seasons. On the other hand, the concentration of heavy metals in the organs were Cd: liver>gills>muscle, $\mathrm{Cr}$ : gills>liver $>$ muscle, $\quad \mathrm{Mn}$ : liver $>$ gills $>$ muscle, $\quad \mathrm{Ni}$ : gills>liver>muscle, $\mathrm{Pb}$ : liver>gills $>$ muscle, during the wet season while the pattern for $\mathrm{Cd}, \mathrm{Cr}$ and $\mathrm{Mn}$ was liver>gills $>$ muscle but for $\mathrm{Ni}$ and $\mathrm{Pb}$ it was liver $>$ muscle $>$ gills.

\section{Conclusion}

Heavy metals have been proven to undergo bioaccumulation in the tissue of aquatic organisms. On consumption of fish and other aquatic organisms these metals could climb up the food chain to man. It can be seen that the fishes in these rivers have been severely affected by heavy metals based on the results obtained 
from this study ( $\mathrm{Cd}, \mathrm{Mn}$ and $\mathrm{Pb}$ ) whose concentrations are above regulatory limits set by WHO and FEPA. The Rivers at the study locations require constant monitoring of prevailing activities in order to control exposure of aquatic life to elevated concentrations of heavy metals. The study also reveals that the heavy metals concentrations in the fish species are not sensitive to the seasonal changes as heavy metals are lost slowly or not at all once bioaccumulated.

\section{CONFLICT OF INTEREST}

The authors declare that they have no conflict of interest.

\section{REFERENCES}

Ambedkar G., Muniyan M. (2011). Bioaccumulation of some heavy metal on the five freshwater fish from kollidam River, Tamilnadu India. Advan in appl Scis. Res., 2(5), 221-225.

APHA (1990), Standard Methods for the Examination of water and wastewater, 17th edition, New York.

Censi, P., Spoto, S. E., Saiano, F., Sprovieri, M., \& Mazzola, S. (2006). Heavy metals in coastal water system.A case study from the North Western Gulf of Thailand. Chemosphere, 64, 1167-1176.

Chindah, A. C., Braide, A. S., Sibeuda, O. C. (2004). Distribution of hydro-carbons and heavy metals in sediment and a crustacean [shrimps - notialis] from the bonney / new Calabar river estuary, Niger Delta. Ajeam - Ragee, (9), 1-14.

Dobson, A. W., Erikson, K. M., \& Aschner, M. (2004). Manganese neurotoxicity. Annals of the New York Academy of Sciences, 1012(1), 115-128.

Ebrahimpour, M., \& Mushrifah, I. (2008) Heavy metal concentrations in water and sediments in TasikChini, a fresh water lake, Malaysia. Environmental Monitoring and Assessment, 141, 297-307.

Emongor, V., Nkegbe, E., Kealotswe, B., Koorapetse, I., Sankwasa, S., \& Keikanetswe, S. (2005). Pollution indicators in Gaborone industrial effluent. Journal of Applied Sciences, 5(1), 147-150.

Eneji, I. S., Sha'Ato, R., \& Annune, P. A. (2011). Bioaccumulation of Heavy Metals in Fish (Tilapia Zilli and Clarias Gariepinus) Organs from River Benue, North-Central Nigeria. Pakistan Journal of Analytical \& Environmental Chemistry, 12(1\&2), 25-31.

European Commission (2000). Amending Commission Regulation (EC) No 194/97. Brussels, Pp. 2-28.

FEPA (Federal Environmental Protection Agency) (2003). Guidelines and standards for Environmental Pollution Control in Nigeria, 238p.
Fernandez, L. G., \& Olalla, H. Y. (2000). Toxicity and bioaccumulation of lead and cadmium in marine protozoan communities. Ecotoxicology and Environmental Safety, 47, 266-276.

Furtado, A. A. L, Albuquerque Leite, R. T., Leite, S. G, \& Pecanha F. R. P. (1998). Effect of hydraulic retention Time on nitrification in an airlift Biological reactor. Brazilian J. Chemical engineering, 15, 1-7.

Heath, A. G. (1991). Water pollution and fish physiology.Lewis publishers. Boca Raton, Florida, USA 35p.

Leland, H. V., \& Kuwabara, J. S. (1985). Trace metals. Gary, M. R., \& Petrocelli, S. R. eds. Fundamentals of aquatic toxicology Hemisphere Publ. Co. New York, Pp. 374-415.

Linnik, P. M., \& Zubenko, I. B. (2000). Role of bottom sediments in the secondary pollution of aquatic environments by heavy metal compounds. Lakes and Reservoirs. Res. Manag., 5(1), 11-21.

Mansouri, B., Baramaki, R., \& Ebrahimpour, M. (2012). Acute toxicity bioassay of mercury and silver on Capoetafusca (black fish). Toxicology and Industrial Health 28(5), 393-398.

Rompala, J. M., Rutosky, F. W., \& Putnam, D. J. (1984). Concentrations of environmental contaminants from selected waters in Pennsylvania. US Fish and Wildlife Service report. State College, Pennsylvania. 102p.

Salati S., \& Moore F. (2010) Assessment of heavy metal concentration in the Khoshk River water and sediment, Shiraz, Southwest Iran.Environmental Monitoring and Assessment 164, 677-689.

Staniskiene, B. , Matusevicius, P., Budreckiene, R., Skibniewska, K. A. (2006) .Distribution of Heavy Metals in Tissues of Freshwater Fish in Lithuania. Polish J. of Environ. Stud., 15(4), 585-591.

Storelli, M. M., A., Storelli, R. D., Morano, R. B., \& Marcotrigiano, G. O. (2005). Trace Elements in loggerhead turtles (Carettacaretta) from the Eastern Mediterranean: Overview and Evaluation Environ. Pollute, 135, 163-170.

USFDA (1993). Food and drug administration, Guidance document for nickel in shell fish.DHHS/PHS/FDA/CFSAN/office of seafood, Washington D.C.

WHO (World Health Organization) (1985). Guidelines for drinking water quality.Vol.1. Recommendations, WHO Geneva.130p. 